\title{
Experiences of Percutaneous Endoscopic Gastrostomy in our Neurology Intensive Care Unit Patients
}

\author{
Nöroloji Yoğun Bakım Hastalarımızda Perkütan Endoskopik Gastrostomi Uygulama \\ Deneyimlerimiz
}

\author{
Levent Öcek ${ }^{1}$, (ه Özge Öcek ${ }^{2}$, (1) Nurullah Damburac1 ${ }^{3}$ \\ 1 Usak University Faculty of Medicine, Department of Neurology, Usak, Turkey \\ 2Usak University Training and Research Hospital, Department of Neurology, Usak, Turkey \\ 3Usak University Faculty of Medicine, Department of General Surgery, Usak, Turkey
}

\begin{abstract}
Objective: Nutritional support has significant clinical importance in patients with poor or no oral intake admitted to neurology intensive care units (NICU). Requirement for, administration methods, and benefits of active enteral feeding with feeding tubes remain a matter of dispute, particularly with respect to patients with impaired swallowing function following central nervous system involvement. In this study, we evaluated the patient characteristics and percutaneous endoscopic gastrostomy (PEG)-related problems in a group of patients in the NICU.

Materials and Methods: Patients undergoing PEG and admitted to our NICU between May 2016 and March 2018 were retrospectively examined. Age, sex, duration of NICU stay, need for mechanical ventilation, occurrence of pneumonia, and PEG-related complications were recorded.

Results: A total of 789 patients admitted to the NICU were screened. PEG use was identified among 41 (5.2\%) of these patients, of whom 23 (56.1\%) were female, with a mean age of $73.66 \pm 17.67$ (range: $32-94)$ years. Twenty-nine $(70.7 \%)$ of these patients with PEG use were diagnosed as having an ischemic etiology, and $7(17.1 \%)$ had hemorrhagic cerebrovascular disease. The mean duration of NICU stay was $48.8 \pm 30.6$ (range: $13-150$ ) days. On average, PEG was used $29.12 \pm 7.97$ (range: 13-42) days after admission. Twelve patients (29.3\%) received mechanical ventilation, and 8 (19.5\%) required a tracheostomy due to prolonged mechanical ventilator support. Prior to PEG, 25 (61.4\%) patients had a diagnosis of pneumonia, and $15(36.6 \%)$ patients developed pneumonia after PEG. PEG-associated nutritional intolerance developed in five (12.2\%) patients.

Conclusion: In agreement with the published literature, PEG-related complications were low in frequency and there were no cases of PEG-related mortality. In neurologic conditions associated with chronic and severe sequela requiring long-term nutritional support, PEG may be preferred on the basis of its ability to provide safe and physiologic nutrition, ease of use, and a low rate of complications.
\end{abstract}

Keywords: Neurology intensive care unit, percutaneous endoscopic gastrostomy, enteral nutrition

\section{$\ddot{\mathbf{O} z}$}

Amaç: Beslenme desteği, oral alımı olmayan ya da yetersiz olan nöroloji yoğun bakım ünitesi (NYBÜ) hastalarında oldukça önemlidir. Santral sinir sistemi etkilenimi sonrasında yutma fonksiyonu bozulan hastalarda beslenme tüpleri yardımı ile aktif enteral beslenme uygulamalarının gerekliliği, nasıl uygulanacağı ve uygulanacak işlemin kazanımları hala tartışmalıdır. Bu çalışmada nörolojik yoğun bakım olgularında perkütan endoskopik gastrostomi (PEG) uyguladığımız hastaların özellikleri ve PEG ile ilişkili sorunları inceledik.

Gereç ve Yöntem: Mayıs 2016-Mart 2018 tarihleri arasında hastanemiz NYBÜ'de yatan ve PEG uygulanımı gerçekleştirilen hastalar retrospektif olarak incelendi. Cinsiyet, yaş, yoğun bakımda kalışsüresi, mekanik ventilatör desteği, pnömoni gelişimi ve PEG ile ilişkili olabilecek komplikasyonlar kaydedildi.

Bulgular: NYBÜ'de takip edilen 789 hastanın dosyası incelendi. Yirmi üçü $(\% 56,1)$ kadın ve 18’i $(\% 43,9)$ erkek, yaş ortalaması 73,66 17,67 (32-94) olan 41 $(\% 5,2)$ hastaya PEG takıldığı saptandı. PEG takılan hastaların 29'u $(\% 70,7)$ iskemik, yedisi $(\% 17,1)$ hemorajik serebrovasküler hastalık tanısı almıştı. Hastaların

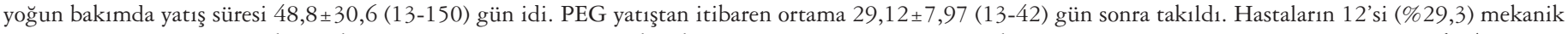
ventilatör desteğinde izlenirken; sekiz hastaya (\%19,5) uzamış mekanik ventilatör desteği nedeniyle trakeostomi açıldı. PEG işlemi öncesinde 25 (\%61,4) hastada pnömoni saptanırken, işlem sonrasında $15(\% 36,6)$ hastada pnömoni geliştiği saptandı. Beş $(\% 12,2)$ olguda PEG ile ilişkili beslenme intoleransı gelişti.

Sonuç: Çalışmamızda PEG uygulanmasına bağlı komplikasyonlar literatür ile uyumlu olarak düşük bulundu ve PEG ile ilişkili mortalite gözlenmedi. Kronik ve ağır sekellere yol açan nörolojik hastalıklarda; uzun süreli nütrisyonel destek gerektiğinden PEG uygulamasının güvenli ve fizyolojik beslenmenin sağlanması, uygulanım kolaylı̆̆ı ve düşük komplikasyon oranları nedeniyle tercih edilmesi gereken bir yöntem olduğu kanısındayız.

Anahtar Kelimeler: Nöroloji yoğun bakım ünitesi, perkütan endoskopik gastrostomi, enteral beslenme

Address for Correspondence/Yazışma Adresi: Levent Öcek MD, Usak University Faculty of Medicine, Department of Neurology, Usak, Turkey Phone: +90 5054989984 E-mail: leventocek66@yahoo.com ORCID: orcid.org/0000-0001-9836-3659

Received/Geliş Tarihi: 23.05.2019 Accepted/Kabul Tarihi: 11.11.2019

${ }^{\circ}$ Copyright 2020 by Turkish Neurological Society

Turkish Journal of Neurology published by Galenos Publishing House. 


\section{Introduction}

One of the basic requirements in patients admitted to neurology intensive care units (NICUs) relates to nutrition. Oral feeding is the preferred route of enteral nutrition. The enteral route should be used as soon as possible in patients with low oral intake in the NICU. Gastric nutrition is a physiologic means of enteral feeding, and the gastric route is the first-line option in patients in the NICU unless contraindicated. The objectives of enteral feeding include the preservation of gastrointestinal mucosal integrity in order to maintain intestinal immune responses and normal flora $(1,2)$.

Currently, gastric tubes are widely used for enteral nutrition. If the requirement for nasogastric (NG) tube feeding is expected to last longer than four weeks, gastrostomy should be scheduled. Percutaneous endoscopic gastrostomy (PEG), originally described by Ponsky and Gauderer (3), is recommended for long-term enteral nutritional support in patients enduring a wide range of chronic neurologic and systemic conditions such as head trauma, cerebrovascular disease, and amyotrophic lateral sclerosis $(4,5,6,7,8,9)$. PEG does not require the transfer of the patient to the operating room, can be applied on patients on mechanical ventilation, and is associated with a low rate of complications. Therefore, it is the most preferred long-term enteral nutrition strategy $(9,10)$. However, PEG is rarely associated with complications at the time of application, as well as during the course of its use $(7,11)$. Herein, we present our results on PEGrelated outcomes, as well as the patient characteristics, in a group of patients admitted to our NICU.

\section{Materials and Methods}

The medical records of a total of 41 patients who received PEG during a NICU stay between May 2016 and March 2018 were retrospectively assessed. Age, sex, primary condition, Glasgow Coma score (GCS), Acute Physiology and Chronic Health Evaluation-2 (APACHE-2) scores, days spent on PEG, the need and timing for invasive mechanical ventilation and tracheotomy, nutritional status prior to PEG, and complications occurring during and after PEG were recorded. PEG was established by a general surgeon with expertise on this field using the "pull" technique, and percutaneous placement of a 20-F gastrostomy tube with a "Roll" type bumper. After the study protocol was approved by the Usak University Faculty of Medicine Institutional Ethics Committee (date: 20.02.2019, protocol number: 17), the data were retrieved from patient files.

\section{Statistical Analysis}

Statistical analyses were performed using the Statistical Package for the Social Sciences (SPSS v.20.0; IBM Corp. Armonk, NY, USA. Released 2011). The normality of the variables was determined using the Kolmogorov-Smirnov test. Normally distributed continuous measurements are presented as mean and standard deviation (SD). Categorical data are shown as percentage (\%). The relationship between PEG and pneumonia were investigated using the chi-square test. A p value of $<0.05$ was considered statistically significant.

\section{Results}

Of the 41 patients included in the study, $23(56.1 \%)$ were female and $18(43.9 \%)$ were male. The mean age of the patients was $73.66 \pm 17.67$ (range: $32-94$ ) years, and the mean duration of NICU stay was $48.8 \pm 30.6$ days. At the time of admission, the mean \pm SD GCS and APACHE-2 scores were 8.5 \pm 1.6 and 17.4 \pm 4.0 , respectively. Twelve $(29.3 \%)$ patients were intubated for mechanical ventilator support at a mean duration of $4.4 \pm 1.5$ (range, 1-12) days after admission. Eight (19.5\%) patients required tracheotomy after a mean of $19.8 \pm 2.6$ days. Twentyeight $(68.3 \%)$ patients were discharged, and $13(31.7 \%)$ died. All deaths were due to the primary conditions requiring NICU admission and were unrelated to the PEG procedure. Table 1 shows a summary of the diagnoses and demographic characteristics of the patients.

An NG tube was placed on the first day of admission in the NICU and enteral feeding was started in all patients except one $(2.4 \%)$, in whom nutritional support involved total parenteral

Table 1. Clinical and demographic data of the patients

\begin{tabular}{|c|c|c|}
\hline & $\mathrm{n}(41)$ & $(\%)$ \\
\hline Age (mean \pm SD) & \multicolumn{2}{|l|}{$73.66 \pm 17.67$} \\
\hline $\operatorname{Sex}(F / M)$ & $23 / 18$ & $56.1 / 43.9$ \\
\hline \multicolumn{3}{|l|}{ Diagnosis } \\
\hline Ischemic stroke & 29 & 70.7 \\
\hline $\mathrm{ICH}$ & 5 & 12.2 \\
\hline SAB & 2 & 4.9 \\
\hline Dementia & 3 & 7.3 \\
\hline Status epilepticus & 1 & 2.4 \\
\hline Encephalitis & 1 & 2.4 \\
\hline GCS $($ mean \pm SD $)$ & \multicolumn{2}{|l|}{$8.54 \pm 1.69$} \\
\hline APACHE-2 (mean \pm SD) & \multicolumn{2}{|l|}{$17.46 \pm 4.00$} \\
\hline $\begin{array}{l}\text { Duration of ICU stay } \\
(\text { mean } \pm \text { SD) }\end{array}$ & \multicolumn{2}{|l|}{$48.85 \pm 30.66$} \\
\hline $\begin{array}{l}\text { Duration of intensive care } \\
\text { stay prior to PEG }(\text { mean } \pm S D)\end{array}$ & \multicolumn{2}{|l|}{$29.12 \pm 7.97$} \\
\hline $\begin{array}{l}\text { Mechanical ventilatory } \\
\text { support (Yes/No) }\end{array}$ & $12 / 29$ & $29.3 / 70.7$ \\
\hline Tracheostomy (Yes/No) & $8 / 33$ & $19.5 / 80.5$ \\
\hline \multicolumn{3}{|l|}{ PEG-related complications } \\
\hline Feeding intolerance & 5 & 12.2 \\
\hline Tube displacement & 4 & 9.8 \\
\hline Local ulceration, bleeding & 1 & 2.4 \\
\hline Procedural difficulties & 0 & 0 \\
\hline \multicolumn{3}{|l|}{ Prognosis } \\
\hline Survival & 28 & 68.3 \\
\hline Death & 13 & 31.7 \\
\hline \multicolumn{3}{|c|}{$\begin{array}{l}\text { F: Female, M: Male, SD: Standard deviation, N: Number of patients, ICH } \\
\text { Intracerebral hematoma, SAB: Subarachnoid bleeding, GCS: Glasgow Coma } \\
\text { scale, APACHE-2: Acute Physiology and Chronic Health Evaluation-2, PEG } \\
\text { Percutaneous endoscopic gastrostomy, ICU: Intensive care unit }\end{array}$} \\
\hline
\end{tabular}


Table 2. Incidence of lung infections before and after percutaneous endoscopic gastrostomy

\begin{tabular}{|llllll} 
& & Yes & No & p \\
Pneumonia & Before PEG (\%) & $25(61.0)$ & $16(39.0)$ & 0.218 \\
PEG: Percutaneous endoscopic gastrostomy & After PEG (\%) & $15(36.6)$ & $26(63.4)$ & \\
\hline
\end{tabular}

nutrition only for the first two days, and a combination of enteral and parenteral routes in the following 10-day period.

The PEG procedure was performed after a mean duration of $29.1 \pm 7.9$ (range, 13-42) days and there were no complications in any cases. Five $(12.2 \%)$ patients experienced feeding intolerance after the procedure. The PEG tube was displaced in four $(9.8 \%)$ patients, and an obstruction of the feeding tube occurred in two $(4.8 \%)$ of these with consequent replacement of the tube. No wound site infections were observed (Table 1).

Pneumonia requiring antibiotherapy was detected in 25 (61\%) patients before PEG, and 15 (36.6\%) patients after PEG (Table 2). However, the mean number of microorganism types that grew in the culture of the endotracheal aspiration sample was $2.8 \pm 1.4$ before the PEG procedure, and $2.4 \pm 1.6$ after. There was no statistically significant difference of lung infection rates before and after PEG $(\mathrm{p}=0.218)$.

\section{Discussion}

Patients admitted to NICUs have a significantly increased risk of malnutrition, requiring nutritional support in a great majority of these subjects. The link between nutritional support and the rate of mortality and morbidity has been clearly established. Several methods have been developed to place feeding tubes to the stomach or jejunum for patients with no prospect of transition to oral feeding within 3 days $(11,12,13,14)$. In the late 1980 s, PEG procedures gained widespread acceptance, with increasingly higher popularity since then, mainly based on the rapidity and safety of the procedure compared with other surgical approaches $(9,15)$.

Long-term percutaneous enteral feeding is used in patients with life expectancy who have no chance of returning to oral feeding. Parenteral nutrition is generally not preferred in such cases due to a number of shortcomings including the associated metabolic disorders, high cost, difficulty of application, as well as patient comfort. Enteral nutrition, as well as enteral feeding with PEG, are recommended in patients with chronic neurologic conditions such as head trauma, cerebral palsy, neuromuscular disorders, and motor neuron disorders $(4,5,6,7,8,9,13,16,17,18,19)$. In a study by Tokunaga et al. (19), $75.3 \%$ of their patients with PEG procedures were reported to have cerebrovascular disease. In coherence with the literature, $87.1 \%$ of our subjects required PEG secondary to cerebrovascular disease.

Despite the general safety of PEG, procedural or postprocedural complications may rarely develop $(20,21)$. The main complications associated with the procedure include bleeding into the abdominal wall or intraperitoneal space. Post-procedural complications include periostomal pain, wound site infection or abscess, necrotizing fasciitis, gastric outlet obstruction, diarrhea, and aspiration (22). In a study by Löser et al. (8), 15\% of patients were reported to have local wound site infection, which was the most frequent early complication in this series. Schurink et al. (20) reported wound site infection and bleeding in $18.7 \%$ and $3 \%$ of their patients undergoing PEG, respectively. The reported 30-day mortality after PEG exhibits a wide variability between $0 \%$ and $28 \%(7,23,24)$. The discrepancy between reported rates of mortality may be related to a number of factors such as the type of neurologic disorder involved, the presence of weight loss exceeding $10 \%$ of the bodyweight, and a forced vital capacity of less than $65 \%$ in respiratory function tests $(7,24)$. In our patient group, there were no deaths or major complications related with PEG. The low rate of complications observed in the present study might be related to the small sample size.

PEG is a preferred method on the basis of the reduced risk of colonization, gastroesophageal reflux, and aspiration, which are commonly observed during long-term use of NG tubes, as well as on the basis of facilitation of patient care and comfort $(13,25)$. Pulmonary aspiration is a common complication in patients receiving nutritional support with NG tubes in the supine position $(14,26)$. The reflux is associated with the impaired relaxation of the lower esophageal sphincter, inadequate esophageal contractions, and the presence of the tube crossing the gastric cardia (14). On the other hand, PEG reduces the risk of aspiration (27). Previous studies have documented a $50 \%$ to $55 \%$ reduction in the growth rates in cultures obtained from tracheal aspiration fluids $(2,27)$. Similarly, many studies have shown that PEG is associated with a reduced likelihood of the aspiration of gastric content, with an associated decrease in hospital admissions due to infection and total hospital costs $(7,14,26,27)$. Likewise, in contrast with $61 \%$ of the patients with lung infections requiring antibiotherapy before PEG, only $36.6 \%$ of our patients required such therapy after PEG.

\section{Conclusion}

In conclusion, although PEG is a more invasive method than NG and nasoenteral routes of nutrition, it may be preferred on the basis of lowered infection risk and treatment costs, in addition to providing more efficient nutrition to patients. We believe that PEG is an effective nutritional strategy that can reduce morbidity and mortality in patients who are unable to receive oral nutrition and who have no prospect of returning to oral nutrition in the long term.

\section{Ethics}

Ethics Committee Approval: Ethical consent was obtained from Usak University Faculty of Medicine Ethics Committee (date: 20.02.2019, protocol number: 17).

Informed Consent: Informed consent was neither required nor obtained due to the retrospective nature of the study.

Peer-review: Externally and internally peer-reviewed. 


\section{Authorship Contributions}

Surgical and Medical Practices: N.D., L.Ö., Ö.Ö., Concept: L.Ö, Ö.Ö., Design: L.Ö., Ö.Ö., N.D., Data Collection or Processing: L.Ö., Ö.Ö., N.D., Analysis or Interpretation: L.Ö., Literature Search: L.Ö., Ö.Ö., Writing: L.Ö., Ö.Ö.

Conflict of Interest: The authors declare that they have no conflict of interest.

Financial Support: There was no source of funding or financial interest in this study.

\section{References}

1. Marik PE, Zaloga GP. Early enteral nutrition in acutely ill patients: a systematic review. Crit Care Med 2001;29:2264-2270.

2. Akıncı İ, Özcan P, Tuğrul S, et al. Percutaneous endoscopic gastrostomy in the ICU. Ulus Travma Derg 2000;6:281-283.

3. Ponsky JL, Gauderer MW. Percutaneous endoscopic gastrostomy: a nonoperative technique for feding gastrostomy. Gastrointest Endosc 1981;27:9-11.

4. Shimizu T, Hanaoka $T$, Hayashi $H$, Inoue $H$, Imamura $K$, Oyanagi $\mathrm{K}$. Percutaneous endoscopic gastrostomy in patients with intractable neurological diseases--retrospective study of the indication, complication and prognosis. Rinsho Shinkeigaku 2007; 47:565-570.

5. ProGas Study Group. Gastrostomy in patients with amyotrophic lateral sclerosis (ProGas): a prospective cohort study. Lancet Neurol 2015;14:702709

6. Czell D, Bauer M, Binek J, Schoch OD, Weber M. Outcomes of percutaneous endoscopic gastrostomy tube insertion in respiratory impaired amyotrophic lateral sclerosis patients under noninvasive ventilation. Respir Care 2013;58:838-844

7. Khokhar N, Gill ML. Percutaneous endoscopic gastrostomy: nine years experience in a tertiary care centre in Pakistan. J Pak Med Assoc 2005;55:108110

8. Löser C, Aschl G, Hébuterne X, et al. ESPEN guidelines on artificial enteral nutrition--percutaneous endoscopic gastrostomy (PEG). Clin Nutr 2005;24:848-861

9. Rahnemai-Azar A, Rahnemaiazar AA, Naghshizadian R, Kurtz A, Farkas DT Percutaneous endoscopic gastrostomy: Indications, technique, complications and management. World J Gastroenterol 2014;20:7739-7751.

10. Gauderer MW, Polsky JL, Izant RJ Jr. Gastrostomy with outh laparatomy: A percutaneus endoscopic technique. J Pediatr Surg 1980;15:872-875.

11. Schrag S, Sharma R, Jaik N, et al. Complications related to percutenaus endoscopic gastrostomy (PEG) tubes. A comprehensive clinical review. J Gastrointestin Liver Dis 2007;16:407-418.
12. Sit M, Kahramansoy N, Tekelioğlu Ü, Ocak T. Perkütan Endoskopik Gastrostomi Uygulamalarındaki Deneyimlerimiz. JAREM 2013;3:66-68.

13. Tian Y, Du HG, Fan CP, et al. Clinical significance of percutaneous endoscopic gastrostomy for patients with severe cranio cerebral injury. Chin J Traumatol 2014:17:341-344.

14. Blumenstein I, Shastri YM, Syein J. Gastroenteric tube feeding; Techniques, problems and solutions. World J Gastroenterol 2014;20:8505-8524.

15. Chen HL, Shih SC, Bair MJ, Lin IT, Wu CH. Percutaneous Endoscopic Gastrostomy in the Enteral Feeding of the Elderly. International Journal of Gerontology 2011;5:135-138.

16. Kirstein MM, Körner S, Schneider A, Manns MP, Petri S, Voigtländer T. Percutaneous endoscopic gastrostomy with and without jejunal extension in patients with amyotrophic lateral sclerosis. Eur J Gastroenterol Hepatol 2018;30:257-262.

17. Sarkar P, Cole A, Scolding NJ, Rice CM. Percutaneous Endoscopic Gastrostomy Tube Insertion in Neurodegenerative Disease: A Retrospective Study and Literature Review. Clin Endosc 2017;50:270-278.

18. Benstead T, Jackson-Tarlton C, Leddin D. Nutrition with Gastrostomy Feeding Tubes for Amyotrophic Lateral Sclerosis. Can J Neurol Sci 2016;43:796-800

19. Tokunaga T, Kubo T, Ryan S, et al. Long-term outcome after placement of a percutaneous endoscopic gastrostomy tube. Geriatr Gerontol Int 2008;8:1923.

20. Schurink CA, Tuynman H, Scholten P, et al. Percutaneous endoscopic gastrostomy: Complications and Suggestion to avoid them. Eur J Gastroenterol Hepathol 2001;13:819-823.

21. Blum Ca, Selender C, Rudy JM, Leon S. The incidence and clinical significance of pneumoperitoneum after percutaneous endoscopic gastrostomy. A review of 722 cases. Am Surg 2009;75:39-43.

22. Finocchiaro C, Galletti R, Rovera G, et al. Percutaneous endoscopic gastrostomy: a long-term follow-up. Nutrition 1997;13:520-523.

23. Burney RE, Bryner BS. Safety and long-term outcomes of percutaneous endoscopic gastrostomy in patients with head and neck cancer. Surg Endosc 2015;29:3685-3689.

24. Sanders DS, Carter MJ, D'Silva J, James G, Bolton RP, Bardhan KD. Survival analysis in percutaneous endoscopic gastrostomy feeding: a worse outcome in patients with dementia. Am J Gastroenterol 2000;95:1472-1475.

25. Moore FA, Feliciano DV, Andrassy RJ, et al. Early enteral feding compared with parenteral reduces postoperative septic complications: The results of a meta-analysis. Ann Surg 1992;216:172-183.

26. McClave SA, DeMeo MT, DeLegge MH, et al. North American Summit on Aspiration in the Critically Ill Pati-ent: consensus statement. JPEN J Parenter Enteral Nutr 2002;26:80-85.

27. Marik PE, Zaloga GP. Gastric versus post-pyloric feeding: a systematic review. Crit Care 2003;7:46-51. 